\title{
GCU
}

Glasgow Caledonian

University

University for the Common Good

\section{Aspiring workers or striving consumers? Rethinking social exclusion in the era of consumer capitalism}

Monticelli, Lara; Baglioni, Simone

Published in:

Contemporary Social Science

DOI:

$10.1080 / 21582041.2017 .1385834$

Publication date:

2017

Document Version

Author accepted manuscript

Link to publication in ResearchOnline

Citation for published version (Harvard):

Monticelli, L \& Baglioni, S 2017, 'Aspiring workers or striving consumers? Rethinking social exclusion in the era of consumer capitalism', Contemporary Social Science, vol. 12, no. 3-4, pp. 316-332.

https://doi.org/10.1080/21582041.2017.1385834

\section{General rights}

Copyright and moral rights for the publications made accessible in the public portal are retained by the authors and/or other copyright owners and it is a condition of accessing publications that users recognise and abide by the legal requirements associated with these rights.

Take down policy

If you believe that this document breaches copyright please view our takedown policy at https://edshare.gcu.ac.uk/id/eprint/5179 for details of how to contact us. 


\title{
Aspiring Workers Or Striving Consumers? Rethinking Social Exclusion In The Era of Consumer Capitalism
}

Lara Monticelli ${ }^{1}$, Post-doctoral Research Fellow, Institute for Humanities and Social Sciences, Scuola Normale Superiore di Pisa (Italy).

Simone Baglioni, Professor of Politics, Yunus Centre for Social Business and Health, Glasgow Calendonian University (UK).

\begin{abstract}
This study is part of a Special Issue aimed at investigating young people's trajectories in troubled and challenging times. The paper tackles the topic by providing the results of an in-depth qualitative and exploratory study conducted on young unemployed people in the Italian city of Turin — the industrial 'capital' of the Sixties and now undergoing a massive wave of deindustrialization. Interviews were gathered in 2010 , when the Great Recession was severely affecting young people living in Southern European countries like Greece, Italy, Spain and Portugal. The article proceeds along two levels of analysis. The first focuses on the subjective experience of unemployment and job precariousness seen through the eyes of young people, aware of living in exceptionally hard and uncertain times. The second focuses on the broad mechanisms leading to social exclusion paying particular attention to deprived experiences of consumption. Findings reveal that while work has not lost its material and symbolic meaning, and a great importance is attributed to experiences of consumption, as a way for young people to socialize with peers.
\end{abstract}

Keywords (5): Social exclusion; Consumption; Unemployment; Precariousness; Youth.

\section{Social exclusion: a literature in need of renewal}

Finding a definition of 'social exclusion' is far from being an easy task. The term is widely used in a wide range of areas in the social sciences: economics, sociology, criminology, policy studies and international relations, as well as official policy reports and a variety of claims produced by politicians, governmental agencies and international institutions ${ }^{2}$. Social exclusion is usually

\footnotetext{
${ }^{1}$ Corresponding author: lara.monticelli@sns.it

${ }^{2}$ See Sealey (2015) for a review.
} 
defined as being a multidimensional concept that refers to deprivation in economic, political, relational, spatial and material spheres of life (Byrne, 2005; Hills et al., 2009; Levitas, 1996). The effort of defining what is social exclusion has often been accompanied by the attempt to relate it to the concepts of poverty and relative deprivation (Church et al.,2000; Lister,2004; Sealey, 2015; Sen, 2000).

Among the most recent critical reviews of how the concept of social exclusion is applied in contemporary social sciences and policy making, the contribution of Clive Sealey (2015) is particularly insightful. Two aspects of Sealey's analysis are relevant for this study. Firstly, his discussion of the linguistic meaning of 'social exclusion' which connects the concept to issues of power. Exclusion, in fact, can be used either with an active or a passive meaning, but 'the idea of active exclusion [...] is that it makes evident that the conditions of disadvantage are caused by the lack of power which individuals have, rather than the expression of their deviant agency' (ibidem, p. 611). In Sealey's words, the excluded people's powerlessness is 'caused by active agents with a specific zero-sum game assertiveness to power, and the maintenance of such power' (ibidem). Secondly, his argument about the nature of social exclusion as a longitudinal (i.e. cross-time) evolving process, an ongoing self-reinforcing vicious circle, rather than a static outcome (ibidem, $p$. 606-607). This point helps to understand that there is difference, in substantive and qualitative terms, between poverty - a static condition (which may be the cause or the consequence of social exclusion), and social exclusion itself - a process.

The definition provided by Pierson (2003, p.7) is in this sense clarifying:

Social exclusion is a process that deprives individuals and families, groups and neighbourhoods of the resources, economies and political activity of society as a whole. This process is primarily a consequence of poverty and low income, but other factors such as discrimination, low educational attainment also underpin it. Through this process people are cut off from their institutions and services, social networks and developmental opportunities that the great majority of society enjoys.

The concept of social exclusion thus implies that the 'excluded' cannot access the 'normal areas of participation of full citizenship' (Percy-Smith, 2000). Social exclusion is often conceived as an 'umbrella concept' (Byrne, 2005) whose features can be inductively derived in opposition to what is considered 'social inclusion', i.e. an array of entitlements, material possessions and social roles that are usually recognized as part of a 'normal life'. 
Among the studies reviewed, the conceptualization of social exclusion and spheres of socialization proposed by Paugam and Gallie's book 'Welfare regimes and the experience of unemployment in Europe' (2000) proves to be particularly illuminating when investigating young unemployed and precarious people. In the book, the authors build on classical sociological thinking to divide social integration (which we understand to mean social inclusion) into three spheres. The primary sphere includes family ties, the secondary sphere friends and acquaintances, and the third sphere refers to connections generated by participation in collective organizations with formalized goals and objectives (e.g. associations, political parties, voluntary organizations etc.). According to this model, as the level of social exclusion increases, socialization shrinks to the primary sphere, i.e. it is limited to family and close friends. This is due to a combination of limited economic, cultural and social resources. Thus, Paugam and Gallie's approach allows for an understanding of social exclusion as a multi-dimensional phenomenon that can be discerned by analyzing people's breadth of socialization across the three spheres.

In parallel with the flourishing of studies deploying the concept of social exclusion over the last two decades (Berghman, 1995; Byrne, 1997, 2005; Hills, 2002; Labonte, 2004; Pierson, 2003; Sen, 2000), more recent contributions have stressed the need to renew and actualize the notion itself and to link it more explicitly with the latest developments in contemporary capitalism and to the effects of the Great Recession on the underprivileged segments of society (Winlow and Hall, 2013). In other words, to connect it more explicitly with the dynamics of power that constitute the preconditions for the persistence and reinforcement of social exclusion itself. Following this line of thought, the traditional Marxian interpretation according to which job insecurity and unemployment are instrumentally used by the owners of capital to maintain a permanent 'reserve army of workers ${ }^{3}$ - keen to re-enter the labour market at the first opportunity, no matter the conditions (Byrne,1997) has been integrated with critical viewpoints arguing that it is necessary to rethink the classic academic discourse on deprivation and social exclusion.

Among this strand of studies, based on the idea that, in contemporary post-industrial societies, the condition of workplace insecurity is being normalized and that the positive symbolism associated with a 'a job for life' is slowly but relentlessly vanishing (Doogan, 2015), Simon Winlow and Steve Hall (2013) posit that unemployed and deprived people nowadays constitute a 'reserve army of consumers' rather than one of workers (ibidem, p. 107). Building their argument on ethnographic studies conducted in North-East England (Winlow, 2001; Winlow and Hall, 2006;

\footnotetext{
3 ، [...] A relatively redundant population of workers, i.e., a population of greater extent than suffices for the average needs of the valorisation of capital, and therefore a surplus-population... It is the absolute interest of every capitalist to press a given quantity of labour out of a smaller, rather than a greater number of labourers, if the cost is about the same... The more extended the scale of production, the stronger this motive. Its force increases with the accumulation of capital' (quote from Karl Marx in 'The Capital: A Critique of Political Economy', Chapter 25, 1867).
} 
Hall et al., 2008), the authors describe how 'those who do not possess the resources to indulge legally in hedonistic consumption with any degree of regularity continue to imagine and mentally calibrate their social value in relation to it' (Winlow and Hall, 2013, p.107). In their recount, instead of assuming a contentious attitude towards the wealthy social classes, the contemporary working classes - the 'precariat' (Standing, 2011, 2014) - are craving to live 'the good life', i.e. the life as it is portrayed by dominant neoliberal ideology, by consumerist culture and by the social imaginary created by the mass-media. The consumption of leisure and 'secondary' goods, like branded clothes or technological items, becomes a relevant aspect of life because of their symbolic value. Therefore, consumption is a crucial experience for the formation of identity and self-identification processes, especially among adolescents and young adults. This argument constitutes the core message of their book- influenced, in particular, by the thoughts of Slavoj Žižek and Jean Baudrillard. Neoliberal ideology is so pervasive that it manages to 'overdetermine' the 'socially excluded ones' and their aspirations, leaving very little, if any, room for solidarity, political mobilizations and emancipatory (re)actions (Winlow and Hall, 2013, pp. 143-151).

Winlow and Hall's work is not the first attempt at investigating social exclusion in relation to consumption and, specifically, to the lack of it. Contemporary philosopher and sociologist Zygmunt Bauman has made substantial contributions to the understanding of the 'homo consumens' in his work on the socialization mechanisms in post-industrial and post-modern societies (Bauman, 2004, 2007, 2011). For example, in his book 'Workers, Consumerism and the New Poor', Bauman illustrates how the 'producer society' has been replaced by the 'consumer society' (Bauman, 2004). If in the former, the vocation towards production can be fulfilled only through a collective endeavour (the act of goods' production), in the 'consumer society' the act of consumption reduces the individual to an atomized, lonely, isolated actor that builds her or his own identity around it. In other words, according to Bauman's interpretation, socialization occurs nowadays through acts of consumption rather than through work. In his words: 'work has lost its privileged position - that of an axis around which all other effort at self-constitution and identity- building rotate. But work has also ceased to be the focus of particularly intense ethical attention in terms of being a chosen road to moral improvement, repentance and redemption' (ibidem, pp. 32-33).

In contrast with this perspective in which individual agency is left with little room to manoeuvre and in which work has lost its intrinsic value, the literature produced by social movement and political participation scholars analyzes the rise of new waves of mobilization and the attempts of contemporary young workers to self-organize and to raise the voice as a reaction to rising precariousness (Bassoli and Monticelli, 2017; Corbetta and Colloca, 2013; Chabanet and 
Faniel, 2012; Choi and Mattoni, 2010; della Porta et al., 2015; Giugni, 2010; Mattoni and Vogiatzoglou, 2014; Monticelli and Bassoli, 2016).

\section{Aim and objectives}

The aim of this article is to investigate, through a qualitative and exploratory analysis, the importance attributed to consumption of both primary and secondary goods among unemployed and precarious youth, as well as the connection between unemployment, lack of consumption and the perception of social inclusion/exclusion.

Concerning the consumption aspect, the analysis has been inspired by Winlow and Hall's critical appraisal (2013), as well Bauman's work introduced earlier (Bauman, 2004, 2007, 2011). This focus on consumption as a meaningful experience in young people's lives is supported by aggregate data which show that despite a deterioration in employment opportunities, people do not stop purchasing and 'consuming' goods. Figure 1 compares the increase in consumption of a number of young people in Europe who are 'Not in Education Nor in Employment or Training' $(\mathrm{NEET})^{4}$ (in percentage) with household expenditure on leisure activities and goods (still in terms of percentage on overall household expenditure). The data in Figure 1 show that despite the growing number of young NEETs, particularly following the effects of the economic and financial crisis in 2008, expenditure on leisure remained stable over time. Moreover, data for Italy ${ }^{5}$ show that when comparing two years, 2005 and 2012, respectively before and after the financial crisis of $2008 / 2009$, the expense for leisure increases from $2.7 \%$ to $3.3 \%$, while in the same period the youth unemployment rate rises from $17.7 \%$ to $25.4 \%$ (Eurostat). The data thus suggests that economic hardship has not affected the importance that leisure consumption is given in people's lives.

By interviewing a sample of long-term unemployed and precarious youth living in the Italian city of Turin during the Great Recession, it is possible to discern, through their own recounts, how the exclusion from the labour market has affected the patterns of consumption of both primary and

\footnotetext{
${ }^{4}$ The definition of NEET provided by Eurostat is: the indicator young people neither in employment nor in education and training, abbreviated as NEET, corresponds to the percentage of the population of a given age group and sex who is not employed and not involved in further education or training. The numerator of the indicator refers to persons meeting these two conditions: they are not employed (i.e. unemployed or inactive according to the International Labour Organisation definition); they have not received any education or training in the four weeks preceding the survey. The denominator is the total population of the same age group and sex, excluding the respondents who have not answered the question 'participation to regular education and training'. In the case of the data presented, the age range considered is 20-34.

| ${ }^{5}$ Available at: http://ec.europa.eu/eurostat/.
} 
leisure goods, and how this deprivation has changed their perception of social exclusion and isolation.

Figure 1. Percentages of expenditure on leisure among NEETs in Europe

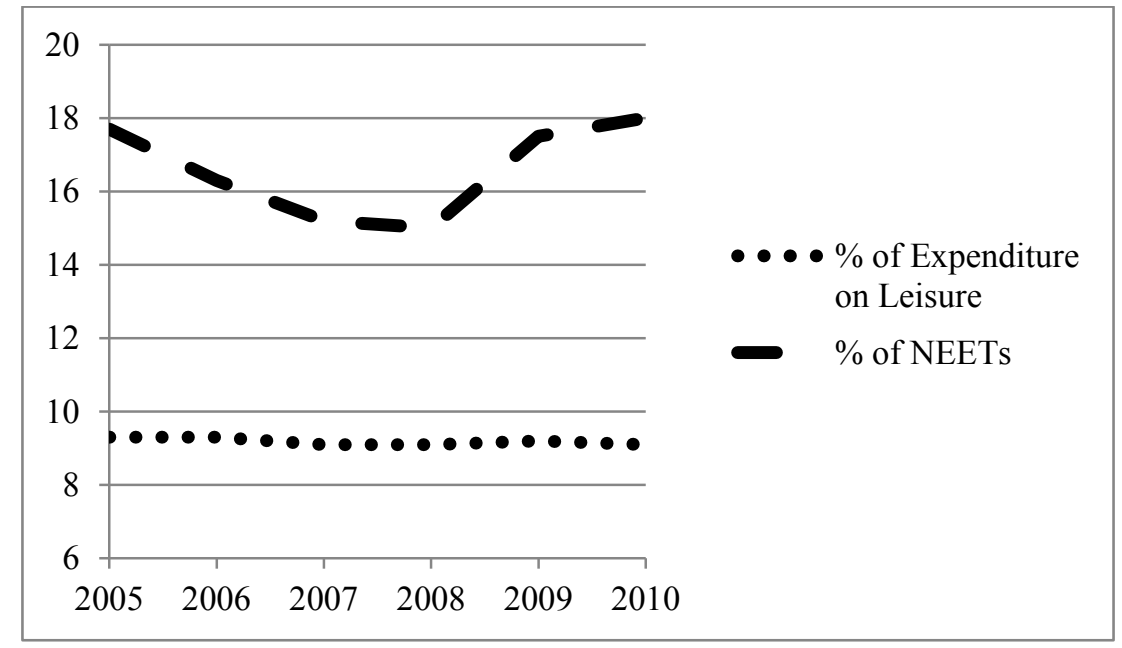

Source: Eurostat.

\section{Methods, sample and context}

This study is based on a qualitative analysis of nineteen in-depth interviews with young unemployed and precarious people living in the Italian city of Turin. Inspired by Grounded Theory (Glaser and Strauss, 1967), the authors used interviews to inductively unfold the multidimensional features of subjective experiences of unemployment. From this they developed theoretical assumptions (Mattoni, 2014) about the role of work and consumption in the formation of trajectories of emancipation. In accordance with the tradition of qualitative research, the interview process was perceived as an interactive exercise. The authors are aware that the findings presented in this article are their own reflection of the interviewees' words, the reflection of two academic researchers who, nonetheless, have observed and been part of the discussed milieu for a long time.

Interviews have been conducted following a loosely structured topic-centred interview schedule (Mason, 1996) based on sensitizing concepts, i.e. concepts suggesting 'directions' where to look for an empirical phenomenon rather than prescriptive instructions on what to see (Blumer, 1954, p. 7, Bowen, 2006). The interview schedule allowed to investigate unemployment against various aspects of life such as social and political embeddedness (questions focusing on social dimensions, civic and political engagement), well-being and sense of belongingness to a given 
group and community, economic-financial situation, experiences with labour market policy and institutions, and future perspectives in life $^{6}$.

The interviewees consisted of seven women and eleven men whose age ranged from 19 to 35 (see Appendix 1), most of them with educational attainment limited to compulsory or secondary levels (only two interviewees had a tertiary education degree). The choice of this age range is justified by the willingness to include individuals who recently concluded the cycle of compulsory education and were trying to enter the labour market for the first time, as well as those who already had some experience of precarious work (and/or unemployment). Moreover, taking into consideration this wide age range allowed the authors to interview people coming from a variety of different households. Although the majority of the interviewees had a partner, only few of them lived with her/him or as an independent household, while most were still living at home with parents or close relatives. In sum, the selected age range allowed to gain an holistic perspective on the experience of precarious work and unemployment among young adults in Italy.

Fifteen of the interviewees were born in Italy, three in Romania, and one in Nigeria (cfr. more detailed information in the Appendix). Young unemployed and precarious workers were primarily recruited at the job desk of a social enterprise in Turin, after which a snowballing technique was used to enlarge the sample. Interviews took place in the premises of the social enterprise itself and in public spaces like cafés, and in one case, upon his demand, the interviewee's flat. Interviews, lasting between one and a half and two hours were all recorded and transcribed. Transcriptions were analysed manually by both authors. Each of them reflected on the data while refining the sensitive concepts used in the preparation of the interview schedule. They shared their reciprocal thinking and exchanged views on each other's interpretative notes. Finally, they elaborated the conceptualisations and understanding of unemployment and consumption as discussed in the paper.

This study was conducted in 2010, a critical socio-economic juncture in which the economic and financial crisis started in 2008 was still peaking in Italy, with dramatic consequences on the country's rate of unemployment, especially among young people ${ }^{7}$. Unemployment had become a salient issue in the public debate and, as such, something that people experiencing it would be more prone to speak about (Gallas, 1996; Monticelli et al., 2016). Nevertheless, the authors did experience a certain degree of reluctance to accept to be interviewed amongst the people at the job desk. It therefore took six months to collect a satisfactory number of interviews. The resulting fieldwork brought to an in-depth disclosure of interviewees' perceptions and experiences of a jobless life in hard times. This provided with a reliable basis for an interpretive, data guided,

\footnotetext{
${ }^{6}$ Interview schedule available on request.

${ }^{7}$ Longitudinal series available at http://ec.europa.eu/eurostat/statistics-explained/index.php/Unemployment_statistics.
} 
analysis of the consequences of unemployment on a group of young people's well-being and sense of belonging in contemporary Western European society.

This study has to be considered in connection with the context in which it was developed, the city of Turin. The city was chosen because it is emblematic of the economic and industrial dismantling occurring in the country and therefore of the declining living conditions amongst bluecollar workers' families. Interviewees, in fact, come mainly from a working class milieu and represent the social group that - due to fewer educational and relational resources - benefited less from the 'tertiarisation' of the economy. Turin has for more than a century been the core of Italian manufacturing industry, hosting the headquarters of the largest national carmaker, FIAT. For decades, it attracted manpower from the poorest Southern Italian regions, and established its role as a centre of the industrial engine, while promoting a model of social integration based on the cities' dualist catholic-communist tradition of civic engagement, associational life, and strong unionisation (Bassoli and Theiss, 2014). However, in the Nineties the country's economic and industrial landscape started to change under the pressure of globalisation and the implementation of neoliberal economic policies (Dunford and Greco, 2006). The waves of de-industrialisation, outsourcing, and deregulation of the labour market reshaped the contours of the labour market. Employment opportunities and social cohesion deteriorated into one of scarce opportunity and social isolation. While the current economic reshaping of the city is creating new opportunities of employment, it has mainly been captured by those endowed with more education and relational resources, leaving low-skilled workers struggling to find employment opportunities (Gallino, 2003; Berta, 2006).

Many of the young unemployed in the sample are daughters and sons of the generation that, during the economic boom that followed the Second World War, migrated from the rural and underdeveloped South to the Northern regions, mainly Lombardy, Emilia-Romagna and Piedmont. During the Nineties, as a consequence of deindustrialization and the outsourcing of manufacturing, many of the blue-collar workers were gradually dismissed and found themselves in a condition of extreme precariousness and at risk of remaining stuck in a condition of permanent unemployment. The story of these interviewees, as it will become clear in the next section, is thus the reflection of a historical, cumulative and inter-generational cycle of social exclusion. 


\section{4. 'A man is nothing without a job'. The material and symbolic value of work among unemployed youth}

The interviews allowed to gather a large amount of empirical material, in the form of long transcriptions $^{8}$. The quotes reported in this section can bring a deeper understanding of the meaning and features of (or lack of) work and the role that consumption plays in processes of social exclusion.

The first topic extrapolated from the interviews is that, as described in other studies focusing on the precarisation of employment relations in Italy (Barbieri and Scherer, 2009; Fullin, 2004), work trajectories are reported as being discontinuous and 'de-standardized' (Elzinga and Liefbroer, 2007), thus leaving little room for developing an independent life and for planning the future. While irregular jobs and fragmented work experiences are sometimes instrumental to pay for further education, more often they are the beginning of non-standard, 'trapped' trajectories of work. As outlined in several analyses of young Italian people's transitions to the labour market, individual trajectories usually follow the typical 'Mediterranean' model characterized by precariousness at the end of studies, prolonged co-habitation within the parents' household and a late departure from it.

'Since the secondary school, I've started working...I started working with an informal contract at 'Orto Gallery' that are stalls selling cheap jewelry...I was employed irregularly but I was still a student so I did not care and having some money in the pockets was good [...]. At the end of the school I worked in a self-service restaurant near Piazza Carlo Alberto, there as well I was employed informally...but working there was not worth the effort, I used to work for eight-nine hours per day for three hundred Euros per month. I worked a few days there but then I felt ill because of the stress. After that I worked in a show room of electronic goods as a secretary.

For how long have you worked there? For 4 months more or less.

Which contract did you have? I was employed irregularly at the beginning and I earned six hundred Euros then she [the employer] wanted to put me under an apprenticeship contract but I refused because of the little amount of money that implied'. Woman, 20 years old.

Many recounts reflect the 'yo-yo transition model' described in the literature : instead of linear advancements in the job market, every slight improvement in terms of job quality and

\footnotetext{
${ }^{8}$ Interviewers' questions, comments and notes have been italicized throughout the quotes.
} 
workplace is often followed by a period of unemployment or by a recoiling in terms of contract or tasks (Biggart and Walther, 2006; Du Bois-Reymond and López Blasco, 2003). The idea mentioned earlier that social exclusion derives from a self-reinforcing cycle of negative episodes, rather than being a static 'snapshot' condition, emerges bluntly from the interviews. Moreover, the Marxian concept of a 'reserve army of workers' really comes to mind when reading the words of this young woman employed through occasional contracts as a shop assistant during periods of peaking sales across the year:

'I worked with an apprenticeship contract at the Decathlon for two months, January and February, I was a cashier during sales. It has been a nice experience like the one I had at Zara in July and August for the summer sales'. Woman, 20 years old.

Together with job precariousness, the importance of having a job to plan an adult life and to emancipate from the family, is expressed with special emphasis among the youngest interviewees:

'For me it is imperative, we can say vital, to be independent economically, I do not want to escape from my family but I think that when you are twenty-five years old it is legitimate to have your own flat, your own life, and because I am unemployed I cannot do it and this is something making me suffer'. Man, 25 years old.

In contrast to the literature which suggests that work has lost its centrality in the production of social meaning and individual identity (Southwood, 2011; Winlow and Hall, 2006), interviewees portray the importance of having a job, linking it with the need to 'give a sense', a 'mission', to their everyday life, otherwise regarded as boring and depressing. The 'positive symbolism' (Winlow and Hall, 2013, p.106) attached to employment expressed by the interviewees, in spite of its contractual or remunerative quality, seems to contradict Winlow and Hall's argument.

'I miss my job. Now, once I have accompanied my child to school at nine o'clock, if you have a job interview or something do to it's ok but otherwise you don't have a busy day, I miss my job...I feel meaningless...I would like to do something, but I can't...I am born to manage or to organize things... [...] So without a job you found yourself in a new world?

Yes, you feel.... [in a world] that does not belong to you, it does not belong to you' Woman, 35 years old. 
Together with a sense of fulfillment and realization at the idea of being employed, the youngest interviewees describe the psychological effects deriving from parents' and relatives' expectations and pressures.

'Not having a job is psychologically hard to bear, it is not a good situation, I feel like a guest in my parents' house, not because I don't like them, but because I think that the time [for leaving the parents] has come....I can't bear this situation, I am stressed and my parents too are stressed as they are worried about my future. I would not say there is a constant conflict among us but there is tension, I can feel some tension...[...] moreover with a girlfriend things get worst when you are unemployed because...well, because when you have a job it is a different social life. Let me phrase this better: having a job makes you more confident, it gives you self-esteem, you believe in yourself $[\ldots]$ being twenty-five years old and having a partner for four years and still not being able to move and live together is a strong constraint on a relationship'. Man, 25 years old.

'I spend my days on Facebook. They have invented this damn computer... what should I do, I drop my CV around, or take documents to my solicitor or to the tribunal'. Woman, 21 years old.

Both material and symbolic significances are at stake. A job is still conceived as one of the main pillars of life:

'A man is nothing without a job'. Woman, 20 years old.

'It is terrible, it is terrible, as I was used to work since I was in my early twenties... I got used to waking up early to go to work... at least I could enjoy that: to be alive in the morning and not to sleep over... I miss that'. Woman, 35 years old.

'I miss the most important part of one's life, a job... actually the most relevant thing in our life is a good health... and I have that... so I miss the second most relevant thing in life...a job, to understand what we want to make out of our life we need a job, [to elaborate] a minimal capacity of planning, a future, ways out....'. Man, 35 years old.

Interviewees describe their 'ideal' job as one with two main characteristics: fulfilling personal aspirations and providing a sense of long-term stability. Previous studies conducted on Italian graduates' school-to-work transitions have underlined that the strategy implemented, once in the labour market, is 'open and circular' (Franchi, 2005), often subject to iterative adjustment processes 
in which young people juggle and struggle to find a compromise between the need to find stable and remunerative employment, and the desire to match it with personal aspirations and vocations (Monticelli, 2014). In this case, despite interviewees' educational attainment levels being in line with the Italian average (Appendix 1), the authors found that they almost systematically end up downgrading their expectations due to the impossibility of fulfilling them.

'Personally, I would wish myself to find a job that I like to be satisfied with myself, this is what I miss. I feel realized in my sentimental life, I found the person of my life with whom I made a child, hence I miss a job and with a job other projects that go with it like a new flat...I miss a job to be satisfied...it would be enough to be satisfied, only that.

Where do you see yourself in five years' time? Where? I hope not here [she laughs] in the same situation because at forty years it would be even more a critical situation... at that age, one will have to content oneself with an ordinary job of cleaner... but with which satisfaction or enthusiasm can you keep on going? And maybe you find yourself crying and saying 'I don't feel realized in my life and would like to go back'. Woman, 35 years old.

'In a years' time, I hope to have a permanent job. In ten years, I would like to have a family to give my children what I haven't got, from nesting to bigger things. I do really hope that in ten years all this will happen'. Woman, 20 years old.

In sum, analyzing young people's perception of their condition of unemployment suggest that, although employment patterns have dramatically changed in post-industrial societies, work has not yet lost its centrality in life. On the contrary, it is still perceived as an essential vehicle of agency, the one allowing young people to move towards an independent, adult life. Moreover, having a job is considered fundamental since it helps shaping and presenting one's own personality and identity while relating to other people, as exemplified by this quote:

'[While I was studying] when I met someone the question was 'What do you do in your life?' and the answer 'Well, I study, actually I am going to graduate soon' and the reply 'Oh nice, interesting'...now when they ask me 'What do you do in your life? Do you work?' and I say 'No, I am looking for a job' 'Ah', that's all, the conversation stops there'. Woman, 25 years old. 
In the next section, deprived experiences of consumption deriving from the lack of financial resources are interpreted in relation to socialization mechanisms and social exclusion.

\section{A reserve army of consumers? Experiences of consumption and patterns of socialization}

The second central theme arising from the interviews, together with the material and symbolic meaning attached to work, is the relationship between unemployment, consumption and social exclusion. Consumption, similarly to work, holds a symbolic value as well. According to Winlow and Hall (2013), the 'ideological incorporation' of what constitutes the 'good life and confers social status' (ibidem, p. 109) is deeply rooted in people's mind. So deeply that even the least wealthy social classes conceive the possession of certain status-goods as a priority (ibidem). In Baudrillard's words ([1970] 1998, p. 81): '(consumption) is something enforced, a morality, an institution. [...]. The consumer society is also the society of learning to consume, of social training in consumption [...]. That is to say there is a new and specific mode of socialization...'.

To what extent is this true amongst the interviewees of this study? What the authors found is that not having the economic resources to go out for a drink, to a club or to the gym is indeed perceived as a missed opportunity to socialize, thus reinforcing the cycle of social exclusion:

'You know there is always this situation when I have to ask my mother to buy a pair of jeans, or shoes. [...] I would like to go swimming, to go to the gym but obviously these are things you need money for and I cannot afford them now so I have no hobby'. Woman, 25 years old.

'No, I don't go to places like pubs and clubs because as you say I don't have the money for it. My friends used to go to these clubs and found a girlfriend there...but you know, I don't have these [gesture for money] and so cannot afford going there. [...] I don't practice any sport, I don't have the money for that either'. Man, missing age.

'It is normal, when you are in your twenties, to desire buying a nice shirt when you see it in the windows but I cannot afford it, I cannot afford spending even fifteen Euros....but when you go for job interviews you meet these ladies who 
look like a model from "The devil wears Prada"9 and they look at you....they humiliate you'. Woman, 20 years old.

Amongst the oldest interviewees, the comparison with the life before unemployment highlights the changes occurred in everyday life experiences, especially referring to consumption patterns:

'Where did you have to cut expenses in your family budget after becoming unemployed? Did you change your way of life or do you manage to get on with the same life? No, I would not say we are able to live the same life, in fact before we could afford going out in the evening or we used to have a pizza on Saturday night somewhere, now we never go out and if we have a pizza then we bake it ourselves or there is always the frozen pizza to eat at home. Also, buying clothes has changed, before I used to go to the market to buy them, which was not such a luxury habits, now I do not go anymore...even buying knickknacks at the market as I did sometimes has become unaffordable, so for sure we cut these expenses'. Woman, 35 years old.

In a few cases, deprivation also affects the consumption of primary goods, so that the interviewees are forced to procure food for them and their offspring at local charities or at the local church. These are cases of profound and deep material destitution, in which the family of origin is also living under similar conditions of poverty and thus can't provide any help. Social exclusion deriving from material deprivation seems thus to be not only a cumulative process taking shape across along the span of a lifetime, but appears to be also an inter-generational phenomenon. All four types of capital (financial, cultural, human and social) identified by Pierre Bourdieu (2003) as elements that lead to social reproduction of inter-generational inequalities, can be recognized. In other words, the interviews show that social exclusion is a process taking shape within and between generations.

'I cannot count on my parents' support as my mother is the only one working at home, and it is already difficult for them to live with her salary and having two more people to feed [herself and her son] would make the situation even harder....I look for my food at the church or in various associations [charities]...three to four times per month and I eat something with that. [...] I don't eat meat, I eat pasta, what should I say...luckily my son eats at school, he can eat meat there and for dinner having a dish of pasta is ok for

\footnotetext{
9 'The Devil Wears Prada' is a 2006 American movie in which a young women, after graduating, starts to work for a famous fashion magazine in New York.
} 
him. In any case I always manage to get something [to eat] from somewhere...an acquaintance, someone from the San Vincenzo charity that calls me when she has cooked the spezzatino [stewed meat] and can give me some of it...eventually she can give me a couple of steaks [...] sometimes they also have five or ten Euros for me. [...] I am nine months behind with my rent.... for an overall amount of nine thousands Euros.

You said you have four brothers, you have a boyfriend, couldn't you borrow some money from them? Oh, my God ... it would be like taking the bread out of their mouth! Absolutely no!

So...It's out of the question, they cannot give me money....'. Woman, 34 years old.

Moreover, in support of Paugam and Gallie's (2000) 'three-tiered' social integration model, interviewees show levels of socialisation limited primarily to the sphere of family and relatives, and seldom to friends and acquaintances, while only one interviewee described a socialisation pattern which included the third sphere (associations and collective action).

'My friends are all gone...my school friends, my university friends, we don't see each other anymore...I go out with my boyfriend and his family members, his sister, his brother in law, they are more or less of our age...I like them'. Woman, 25 years old.

The opportunities to hang out with friends and acquaintances are very limited, although it remains unclear whether this is caused by the lack of monetary resources, of social capital, or by some kind of self-inflicted stigma that prevents to look for socialization opportunities. When speaking about 'spaces' for socialization, they only refer to their home or their parents' one. Again, in line with Paugam and Gallie's assumptions one interviewee says:

'With friends one [an unemployed person] has to say no to many things, instead of seeing them four times a week you see them once, maybe twice, to see them you are forced to move, to go in clubs....of course one does not take a drink but fuel does cost and it is rare that when we go out with friends we do not go in a club or similar place'. Man, 35 years old.

'We don't have friends [she refers to herself and her husband] apart from my two brothers that are more or less of our age with their girlfriends, so we used to go out with them and their friends but for me these were not 'my friends', and I did not like them....so basically we are alone, we spend our evenings among ourselves, you and me, 
me and you... always like that and at 35 years old you feel like an old person'. Woman, 35 years old.

However, the picture emerging from the interviews is quite different from Winlow and Hall's recounts from North-East England (Winlow, 2001; Winlow and Hall, 2006; Hall et al., 2008). 'They want big screen TV, flash cars, new clothes, foreign holidays rather then forge new solidarities, to elevate themselves above those around them', report the authors in their recent book which attempts to describe how consumerist ideology is nowadays shaping people's desires and aspirations (Winlow and Hall, 2013, p. 108). In this case study, a reference to a comparable ambition for luxury consumption is hard to find. Nonetheless, the issue of consumption appears to be articulated and expressed along two thematic lines: the first one concerns consumption of goods as a primary need and a necessity (especially when related to food and shelter), the second one relates to secondary-leisure goods as a tool that eases socialization mechanisms among young people and helps with the formation of one's own personality and identity. The interviewees can be divided into two ideal-typical groups: on the one side there are those who cannot count on the support of their relatives (parents and partners) and thus struggle even to buy food and other primary goods; on the other side, are those who are still living with their parents, who can still afford, although in a limited manner, secondary goods and leisure opportunities.

\section{Concluding remarks and perspectives for further research}

In this article, the authors discussed the perception of social exclusion among a group of young unemployed and precarious people living in the Italian city of Turin. A former economic and industrial centre, the city has dramatically changed its economic profile due to post-industrialization dynamics. The manufacturing industry has shrunken and a tertiary sector has developed to replace it. Therefore, working opportunities in the city do not appeal to all but to the segment of young people with higher cultural and educational capital. The others, primarily young people from bluecollars families have limited income and scarce opportunities to plan for the future and foresee a passage into an adult, independent life.

A wealth of literature has investigated the effect of unemployment and precariousness on peoples' lives, with specific attention paid to the detrimental consequences of joblessness on wellbeing, sense of belonging to communities, capacity to plan ahead and transitioning to adulthood. This study contributes to the debate by investigating how unemployment affects socialization patterns through deprived experiences of consumption, as most young people (although not only) use consumption as a tool to socialize and forge their identities. 
Succinctly put, the in-depth interviews reveal that employment is still considered a formative experience of life and that young unemployed people express regret and suffering for not having a job. Moreover, they feel that their jobless status jeopardizes their social 'value' and their social standing in society. What is not found in their discourses, though, are references to unemployment as a stigma. Perhaps the chronic Italian (and Southern European) double-digit rate of youth unemployment has changed ordinary people's perceptions, and therefore a jobless status has ceased being interpreted, at least among the interviewees, as a stigmatizing condition. Still, from an individual view-point, unemployment continues to be a situation which causes anxiety and a pessimistic outlook. Furthermore, the interviews tell a story of social exclusion as a longitudinal, inter-generational process - one in which deprivation is in some cases 'inherited' from parents who have been unable themselves to navigate the changed economic landscape.

Despite expressing feelings of powerlessness, the young people interviewed were striving to maintain their capacity and agency to deal with challenging circumstances, albeit they did not take any form of public stance, and did not engage in collective action to affect the political arena. In the future, though, the claims of this youth could perhaps take the shape of a collective voice and gain political visibility if it was mobilized by civil society associations, social movements and political leaders. At the moment of writing, there is anecdotal evidence suggesting that this may already be underway, given the recent election in June 2016 of the thirty-one-year-old mayor of Turin, Chiara Appendino, from the populist Five Star Movement.

Turning to consumption, interviewees also evidenced the ordinary features of young people living in a modern society by attributing value to consumption as a way of gaining social status and socializing with friends and acquaintances. Socialization occurs mainly with family and relatives the primary tier of socialization - and when it moves beyond it, it is inextricably related to experiences of consumption: drinking a beer or going to the restaurant or the club. Hence, limited economic resources due to joblessness become inhibitors of social life and contribute to a perceived sense of social exclusion.

In contrast to the accounts about unemployed and deprived people in the United Kingdom (Winlow, 2001; Winlow and Hall, 2006; Hall et al., 2008) although, in this case-study consumption does not seem to be perceived as having a symbolic value per se. One could hypothesize that the phenomenon of 'ideological incorporation' (ibidem) is therefore not as ingrained in the imagination of unemployed Italian young people as it is in the British case. Indeed, interviewees in this study perceive experiences of consumption instrumentally - as a means to socialize.

To conclude, consumption of leisure goods appears to be intrinsically intertwined with socialization and, ultimately, subjective feelings of social inclusion and integration. Despite the 
existence of an extensive network of third-sector voluntary organizations, cultural-political associations (like ARCI - Italian Recreational Cultural Association) and autonomous 'centri sociali' (occupied spaces by grassroots activists) in Turin, interviewees were all unaware that these spaces and organizations could provide opportunities for 'un-commodified' and politically engaged moments of socialization. Investigating the reasons behind this distance is certainly worth further and more in-depth analysis.

\section{Acknowledgements}

The data analyzed in this paper are the result of the research project YOUNEX - 'Youth, Unemployment, and Exclusion in Europe: A Multidimensional Approach to Understanding the Conditions and Prospects for Social and Political Integration of Young Unemployed' (Grant Agreement no. 216122). The authors are grateful to Matteo Bassoli who helped collecting the interviews during the fieldwork in 2010 and to all the members of the international research consortium.

\section{Disclosure statement}

No financial interest or benefit has arisen from the applications of this research.

\section{Biographical notes}

Lara Monticelli is post-doctoral research fellow at Scuola Normale Superiore di Pisa (Italy). Her research is centered on the study of political participation in its various forms, social movements, prefigurative politics and alternative, sustainable lifestyles.

Simone Baglioni is Professor of Politics in the Yunus Centre for Social Business and Health at Glasgow Caledonian University (UK). He is the coordinator of the EU Horizon 2020 project SIRIUS and the principal investigator in the "TransSol" and "Fab-Move" projects dealing with social innovation and collective actions issues. 


\section{References}

Barbieri P. e Scherer S. (2009). Labour Market Flexibilisation and its Consequences in Italy, European Sociological Review, Vol.3, 677-692. doi: 10.1093/esr/jcp009.

Bassoli, M. and Theiss, M. (2014). Inheriting Divisions? The Role of the Catholic and Leftist Affiliation in Local Cooperation Networks: The Case of Italy and Poland in Baglioni, S. and Giugni, M. (eds.) Civil Society Organizations, Unemployment and Precarity in Europe, (pp. 175-203), Houndmills: Palgrave Macmillan.

Bassoli, M. and Monticelli, L. (2017). What About the Welfare State? Exploring Precarious Youth Political Participation in the Age of Grievances. Acta Politica, 1-27 (advance online publication). doi: 10.1057/s41269017-0047-z.

Baudrillard, J. (2008). The Consumer Society: Myths and Structures. London: Sage.

Bauman, Z. (2011). Collateral Damage: Social Inequalities in A Global Age. Cambridge: Polity Press.

Bauman, Z. (2005). Work, Consumerism and The New Poor. Maidenhead: Open University Press.

Bauman, Z. (2007). Consuming life. Cambridge: Polity Press.

Berghman, J. (1995). Social Exclusion in Europe. Policy Context and Analytical Framework. in Room, G. (ed.) Beyond the Threshold, Bristol: Policy Press.

Berta, G. (2006) L'Italia delle fabbriche: ascesa e tramonto dell'industrialismo nel Novecento, Bologna: il Mulino.

Biggart, A., and Walther, A. (2006). Coping With Yo-yo-Transitions: Young Adults Struggle for Support, Between Family and State in Comparative Perspective. In Leccardi, C. and Ruspini, E. (eds.) A New Youth? Young People, Generations and Family Life, (pp. 41-62), Abingdon: Routledge.

Blumer, H. (1954). What Is Wrong with Social Theory? American Sociological Review Vol. 19(1), 3-10.

Bowen, G. A. (2006). Grounded Theory and Sensitizing Concepts. International Journal of Qualitative Methods Vol. 5(3), 12-23. doi: 10.1177/160940690600500304.

Bourdieu, P. (2003). Cultural Reproduction and Social Reproduction. In Jenks, C. (ed.) Culture: Critical Concepts in Sociology, Vol. 1 (pp. 63 -100). London: Routledge.

Byrne, D. (1997). Social Exclusion and Capitalism. Critical Social Policy, Vol. 17 (1), $27-51$. doi: $10.1177 / 026101839701705002$.

Byrne, D. (2005) Social Exclusion (2nd Edition), Maidenhead: Open University Press.

Chabanet, D., and Faniel, J. (eds.) (2012). The mobilization of the unemployed in Europe: from acquiescence to protest? New York: Palgrave Mcmillan US.

Choi, H. L., and Mattoni, A. (2010). The Contentious Field of Precarious Work in Italy: Political Actors, Strategies and Coalitions. Journal of Labor and Society, Vol. 13(2), 213-243. doi: 10.1111/j.1743-4580.2010.00284.x

Church, A., Frost, M., and Sullivan, K. (2000). Transport and social exclusion in London. Transport Policy, Vol. 7(3), 195-205. doi: 10.1016/S0967-070X(00)00024-X.

Corbetta, P., and Colloca, P. (2013). Job Precariousness and Political Orientations: The Case of Italy. South European Society and Politics, 18(3), 333-354. doi: 10.1080/13608746.2013.769791.

Della Porta, D., Hanninen, S., Siisianen, M. and Silvasti, T. (2015). The New Social Division. Making and Unmaking Precariousness. Basingstoke: Palgrave Mcmillan UK.

Doogan, K. (2015). Precarity - Minority Condition or Majority Experience?. In della Porta, D., Hanninen, S., Siisianen, M. and Silvasti, T. (eds.) The New Social Division. Making and Unmaking Precariousness (pp. 43-62). Basingstoke: Palgrave Macmillan UK. 
Du Bois-Reymond, M., and López Blasco, A. (2003). Yo-yo Transitions and Misleading Trajectories: Towards Integrated Transition Policies for Young Adults in Europe. In Lòpez Blasco, A., Mcneish, W. and Walther, A. (eds.) Young People and Contradictions of Inclusion. Towards Integrated Transition Policies in Europe, (pp. 1941). Brisol: Policy Press.

Dunford, M., and Greco, L. (2006). After the three Italies: Wealth, inequality and industrial change. Malden, MA: Blackwell Publishing.

Elzinga, C. H., and Liefbroer, A. C. (2007). De-standardization of family-life trajectories of young adults: A crossnational comparison using sequence analysis. European Journal of Population/Revue européenne de Démographie, 23(3-4), 225-250. doi: 10.1007/s10680-007-9133-7.

Franchi M., (2005). Mobili alla meta. I giovani tra Università e lavoro, Rome: Donzelli Editore.

Fullin, G. (2004). Vivere l'instabilità del lavoro. Bologna: Il mulino.

Gallas, A. (1996). Politische Wirkungsmöglchkeiten von Arbeitlosen in Wolski-Prenger, F. (ed.) Arbeitlosenarbeit. Erfahrungen. Konzepte. Ziele. (pp. 169-186). Opladen: Leske und Budrich,.

Gallino, L. (2003). La scomparsa dell'Italia industriale, Torino: Einaudi.

Giugni, M. (Ed.) (2010). The contentious politics of unemployment in Europe: Welfare states and political opportunities. Basingstoke: Palgrave Mcmillan UK.

Glaser, B. and Strauss, A. (1967). The Discovery of Grounded Theory, Chicago: Aldine.

Hall, S., Winlow, S. and Acrum, C. (2008). Criminal Identities and Consumer Culture: Crime, Exclusion and the New Culture of Narcissism. Devon: Willan Publishing.

Hills, J. (2002). Does a focus on 'Social Exclusion' change the policy response?, in Hills, J., LeGrand, J. and Piachaud, D. (eds.) Understanding Social Exclusion, (pp. 226-243), Oxford: Oxford University Press.

Hills, J., Sefton, T. and Stewart, K. (2009). Conclusions: Climbing Every Mountain or Retreating From Every Foothills?, in Hills, J., Sefton, T. and Stewart, K. (eds), Towards a More Equal Society?, (pp. 341-360). Bristol: Policy Press.

Labonte, R. (2004). Social Inclusion/Exclusion: Dancing the Dialectic, Health Promotion International, Vol 19. No 1, 115-121. doi: 10.1093/heapro/dah112.

Levitas, R. (1996). The Concept of Social Exclusion and the New Durkheimian Hegemony. Critical social policy, Vol. 16(46), 5-20. doi: 10.1177/026101839601604601.

Lister, R. (2004). A politics of recognition and respect: involving people with experience of poverty in decisionmaking that affects their lives. In Andersen, J. and Birte, S. (eds.) The politics of inclusion and empowerment (pp. 116-138). Basingstoke: Palgrave Macmillan UK.

Mason, J. (1996), Qualitative Researching, London: Sage.

Mattoni, A. (2014) The Potential of Grounded Theory in the Study Social Movements in della Porta, D. (ed.), (pp. 2142) Methodological Practices in Social Movements Research, Oxford: Oxford University Press.

Mattoni, A. and Vogiatzoglou, M. (2014). Italy and Greece: Before and After the Crisis: Between Mobilization and Resistance Against Precarity. Quaderni: Communication, technologies, pouvoir. Vol. 84, 57-71. doi: 10.4000/quaderni.805.

Monticelli, L. (2014). Scalatori o Prigionieri del Mercato del Lavoro? Uno Studio sulle Traiettorie Occupazionali dei Giovani Laureati Italiani (Unpublished doctoral dissertation). Università degli studi di Brescia, Italy.

Monticelli, L. and Bassoli, M. (2016). Precarious Voices? Types of 'Political Citizens' and Repertoires of Action Among European Youth. PArtecipazione e COnflitto (PACO). Vol. 9(3). doi: 10.1285/i20356609v9i3p824. 
Monticelli, L., Baglioni, S. and Bassoli, M. (2016). Youth Long-term Unemployment and Its Social Consequences in Italy: 'In a World that Does Not Belong to Me' in Lahusen, C. and Giugni, M. (eds.) Experiencing Long-term Unemployment in Europe. Youth on the Edge. (pp. 139-169). Basingstoke: Palgrave Mcmillan.

Percy-Smith, J. (ed.) (2000). Policy Responses to Social Exclusion. Towards Inclusion?, Buckingham: Open University Press.

Paugam, S. and Gallie, D. (2000). Oxford: Oxford University Press.

Pierson, J. (2003). Tackling Social Exclusion. London: Routledge.

Sealey, C. (2015). Social exclusion: re-examining its conceptual relevance to tackling inequality and social injustice. International Journal of Sociology and Social Policy, Vol. 35(9/10), pp. 600-617. doi: 10.1108/IJSSP-05-2014-0040.

Sen, A. (2000). Social Exclusion: Concept, application, and scrutiny. Social Development Papers No. 1. Asian Development Bank. Retrieved online from: https:/www.adb.org/sites/default/files/publication/29778/socialexclusion.pdf.

Southwood, I. (2011). Non Stop Inertia. Alrlesford: Zero Books.

Standing, G. (2011). The Precariat: The New Dangerous Class. London: Bloomsbury Publishing.

Standing, G. (2014). A Precariat Charter: From Denizens to Citizens. London: Bloomsbury Publishing.

Winlow, S. (2001). Badfellas: Crime, Tradition and New Masculinities. London: Bloomsbury Publishing.

Winlow, S., and Hall, S. (2006). Violent night: Urban Leisure and Contemporary Culture. Oxford: Berg.

Winlow, S., and Hall, S. (2013). Rethinking Social Exclusion: The End of The Social? London: Sage. 
Appendix 1. List of interviewees (age, sex and household features)

\begin{tabular}{|c|c|c|c|c|c|c|}
\hline $\operatorname{Age}^{10}$ & Sex & Education & Household $^{11}$ & Partner & $\begin{array}{c}\text { Place of } \\
\text { birth }\end{array}$ & $\begin{array}{l}\text { Additional } \\
\text { info }\end{array}$ \\
\hline 19 & M & $\begin{array}{l}\text { Compulsory }+ \\
\text { professional training }\end{array}$ & $\begin{array}{l}\text { 3) Divorced mother } \\
\text { (employed), older brother } \\
\text { (unemployed) }\end{array}$ & yes & Italy & Private house \\
\hline 20 & M & $\begin{array}{l}\text { Compulsory }+ \\
\text { professional training }\end{array}$ & $\begin{array}{l}\text { 4) Parents, (housewife, } \\
\text { employed), older sister } \\
\text { (unemployed) }\end{array}$ & no & Italy & l \\
\hline 21 & M & Compulsory & $\begin{array}{l}\text { 8) Parents (employed), } 2 \text { older } \\
\text { sisters (single unemployed } \\
\text { mother, employed), } 2 \text { younger } \\
\text { brother (student), } 1 \text { nephew } \\
\text { (toddler) }\end{array}$ & yes & Italy & I \\
\hline 19 & M & Compulsory & $\begin{array}{l}\text { 5) Mother (housewife), } \\
\text { younger brothers (student), } \\
\text { partner }\end{array}$ & yes & Italy & $\begin{array}{l}\text { The father } \\
\text { lives on his } \\
\text { own }\end{array}$ \\
\hline 29 & M & n.a. & Living with his cousin & yes & Romania & None \\
\hline 20 & $\mathrm{~F}$ & Tertiary & $\begin{array}{l}\text { 4) Parents (both employed), } \\
\text { younger sister (student) }\end{array}$ & yes & Italy & Mortgage \\
\hline 21 & $\mathrm{~F}$ & Secondary & $\begin{array}{l}\text { 4) Parents, (housewife, on } \\
\text { unemployment benefit), older } \\
\text { brother(unemployed) }\end{array}$ & yes & Italy & Mortgage \\
\hline 30 & $\mathrm{~F}$ & Compulsory & 3) Living with friends & no & Nigeria & $\begin{array}{l}\text { Precarious } \\
\text { housing } \\
\text { conditions }\end{array}$ \\
\hline 35 & $\mathrm{~F}$ & Compulsory & 2) Single mother & yes & Italy & $\begin{array}{l}\text { Social } \\
\text { housing }\end{array}$ \\
\hline 26 & M & Compulsory & $\begin{array}{l}\text { He lives between Turin and his } \\
\text { hometown }\end{array}$ & yes & Italy & / \\
\hline 34 & $\mathrm{M}$ & Secondary & 3) Parents (pensioners) & no & Italy & 1 \\
\hline 24 & $\mathrm{M}$ & Compulsory & 2) Brother & no & Italy & Rented flat \\
\hline 19 & $\mathrm{M}$ & Tertiary & 4) Parents (employed), partner & yes & Romania & l \\
\hline n.a. & M & Secondary & $\begin{array}{l}\text { 5) Parents (housewife, social } \\
\text { assistance), older brother (part- } \\
\text { time employed), younger sister }\end{array}$ & No & Italy & Rented flat \\
\hline
\end{tabular}

${ }^{10}$ At time of interview (2010).

${ }^{11}$ The number in parenthesis refers to the number of household members. 


\begin{tabular}{|c|c|c|c|c|c|c|}
\hline 25 & M & Secondary & $\begin{array}{r}\text { (unemployed) } \\
\text { pensioner), younger sister } \\
\text { (student) }\end{array}$ & Yes & Italy & Private house \\
\hline 25 & F & Secondary & 3) Partner, his parents & yes & Italy & $/$ \\
\hline 32 & M & Secondary & 2) Wife (employed) & yes & Romania & Italy \\
\hline 35 & F & Secondary & $\begin{array}{r}\text { 3) Partner (employed), son } \\
\text { (student) }\end{array}$ & yes & Rented flat \\
\hline 23 & F & Primary & $\begin{array}{r}\text { 3) Husband (unemployed), son } \\
\text { (toddler) }\end{array}$ & yes & Italy & / \\
\hline
\end{tabular}

